\title{
PENGARUH KUALITAS PELAYANAN TERHADAP KEPUASAN KONSUMEN PADA FIFGROUP DI LUMAJANG
}

\author{
Dimas Julius Hari Kencana ${ }^{a}$, Agustin HP ${ }^{b}$, Bagus Qomaruzzaman Ratu Edi ${ }^{c}$ \\ ${ }^{a}$ Mahasiswa STIE Mandala Jember \\ ${ }^{b}$ Dosen STIE Mandala Jember, agustin@stie-mandala.ac.id \\ ${ }^{c}$ Dosen STIE Mandala Jember, bagus@stie-mandala.ac.id \\ E-mail Penulis Korespondensi : agustin@stie-mandala.ac.id
}

I N F O A R T I K E L

Riwayat Artikel:

Dikirim 20 Februari 2021

Direvisi 20 Maret 2021

Diterima 27 April 2021

Keywords:

Service Quality, Customer Satisfaction

Kata Kunci:

Kepuasan Pelanggan,

Kualitas Layanan

\section{A B S T R A C T}

This study entitled The Influence Of Service Quality On Customer Satisfaction In Fifgroup In Lumajang with the aim of knowing and analyzing the effect of service quality consisting of physical evidence, reliability, responsiveness, assurance and partial empathy on consumer satisfaction at FIFGROUP Yosowilangun Branch Lumajang Regency and to find out and analyzing the effect of service quality consisting of physical evidence, reliability, responsiveness, assurance and empathy simultaneously on customer satisfaction at FIFGROUP Yosowilangun Branch Lumajang Regency. The number of samples in this study was 60 using purposive sampling technique. purposive sampling is a sampling technique using certain criteria. The testing and analysis used in this research is the data instrument test which includes the validity test and reliability test, and the classical assumption test which includes the normality test, multicollinearity test, and heteroscedasticity test, multiple linear regression analysis, the coefficient of determination and hypothesis testing which includes testing $t$ and F test. And the results of this study: 1.) There is no effect of physical evidence on customer satisfaction at FIFGROUP Lumajang 2.) There is no effect of reliability on customer satisfaction at FIFGROUP Lumajang 3.) There is no effect of responsiveness on customer satisfaction at FIFGROUP Lumajang 4.) There is a guarantee effect on customer satisfaction at FIFGROUP Lumajang Branch 5.) There is no influence of empathy on customer satisfaction at FIFGROUP Lumajang. Suggestions from this study to further improve customer satisfaction need to increase again from employees in the company in serving consumers because these employees interact directly with consumers, especially in punctuality as well. So that it will make consumers satisfied and not hesitate to use the company's services again. 


\section{A B S T R A K}

Penelitian ini berjudul Pengaruh Kualitas Pelayanan Terhadap Kepuasan Pelanggan Pada Fifgroup Di Kabupaten Lumajang dengan tujuan untuk mengetahui dan menganalisis pengaruh kualitas pelayanan yang terdiri dari bukti fisik, keandalan, daya tanggap, jaminan dan empati parsial terhadap kepuasan konsumen pada FIFGROUP Cabang Yosowilangun Kabupaten Lumajang dan untuk mengetahui dan menganalisis pengaruh kualitas pelayanan yang terdiri dari bukti fisik, keandalan, daya tanggap, jaminan dan empati secara simultan terhadap kepuasan pelanggan pada FIFGROUP Cabang Yosowilangun Kabupaten Lumajang. Jumlah sampel dalam penelitian ini adalah 60 dengan menggunakan teknik purposive sampling. purposive sampling adalah teknik pengambilan sampel dengan menggunakan kriteria tertentu. Pengujian dan analisis yang digunakan dalam penelitian ini adalah uji instrumen data yang meliputi uji validitas dan uji reliabilitas, serta uji asumsi klasik yang meliputi uji normalitas, uji multikolinearitas, dan uji heteroskedastisitas, analisis regresi linier berganda, koefisien determinasi dan pengujian hipotesis yang meliputi pengujian $t$ dan uji F. Dan hasil penelitian ini : 1.) Tidak ada pengaruh bukti fisik terhadap kepuasan pelanggan di FIFGROUP Lumajang 2.) Tidak ada pengaruh kehandalan terhadap kepuasan pelanggan di FIFGROUP Lumajang 3.) Tidak ada pengaruh daya tanggap terhadap kepuasan pelanggan di FIFGROUP Lumajang 4.) Ada pengaruh jaminan terhadap kepuasan pelanggan di FIFGROUP Cabang Lumajang 5.) Tidak ada pengaruh empati terhadap kepuasan pelanggan di FIFGROUP Lumajang. Saran dari penelitian ini untuk lebih meningkatkan kepuasan pelanggan perlu ditingkatkan lagi dari karyawan di perusahaan dalam melayani konsumen karena karyawan tersebut berinteraksi langsung dengan konsumen terutama dalam ketepatan waktu juga. Sehingga akan membuat konsumen puas dan tidak ragu lagi menggunakan jasa perusahaan.

\section{PENDAHULUAN}

Dalam era globalisasi terdapat banyak berubahan dalam perekonomian masyarakat serta dari setrategi yang di jalankan setiap perusahaan khususnya dibidang leasing yang begitu banyak diminati oleh masyarakat, apalagi dimasa pandemic seperti sekarang ini. Banyak dari masyarakat saat ini yang begitu terdesak dari segi keuangan dan apalagi yang bekerjapun banyak yang di PHK sehingga masyarakat sekarang tidak ada pilihan lagi selain untuk berwirausaha mandiri dirumah.Akan tetapi yang menjadi permasalahannya adalah modal untuk membuka usaha itu sendiri.Sehingga dalam hal ini sangatlah pas keberadaan perusahaan leasing dapat membantu masyarakat meminjamkan modal dengan jaminan tertentu dan termasuk FIFGROUP salah satu perusahaan leasing ternama. 
Perusahaan yang bergerak dalam bidang leasing berupaya untuk memuaskan sebuah konsumen lama ataupun baru. Maka setiap perusahaan harus memaksimalkan kinerja lapang utntuk mendapatkan suatu keberhasilan atau terwujudnya sebuah kesuksesan dalam persaingan pasar. Kemenangan atau tidaknya suatu persaingan tergantung pada kepuasan konsumennya. Memberikan kualitas pelayanan yang baik adalah suatu motivasi bagi karyawan maupun perusahaan dalan mempertahankan konsumennya yang artinya konsumen tersebut sangat puas terhadap pelayanan yang di berikan oleh perusahaan. Dari segi ekonomi setiap orangpun harus terjaga maka kebutuhan setiap rumah tangga terutama di daerah Yosowilangun kabupaten Lumajang kebanyakan masyarakat mempunyai BPKB untuk dijadikan jaminan. Dari setiap perusahaan pasti berfikir keras untuk menonjolkan suatu kualitas termasuk dalam pelayanan untuk konsumen agar konsumen dapat merekomendasikan produknya termasuk jasa leasing ini agar meningkatkan suatu target setiap perusahaan agar perusahaan dapat dipercaya di setiap tempat manapun. Maka terbentuklah kualitas pelayaan yang harus di tingkatkan kembali. Dalam zeithaml dkk, 2009:111 (dalam jurnal Apriyani 2017:3) mengukur dimensi dalam kualitas pelayanan, yaitu: Tangible (Bukti Langsung) Meliputi penampilan fasilitas fisik, peralatan, pegawai dan material yang dipasang. Reliability (Keandalan) Kemampuan untuk memberikan jasa yang dijanjikan dengan handal dan akurat. Responsiveness (Daya Tanggap) Kemauan untuk membantu konsumen dan memberikan jasa dengan cepat.Assurance (Jaminan) Pengetahuan, sopan santun, dan kemauan karyawan untuk menimbulkan keyakinan dan kepercayaan.Empathy (Empati / kepedulian) Kepedulian dan perhatian secara pribadi yang diberikan kepada pelanggan.

\section{METODE PENELITIAN}

\section{Populasi dan Sempel}

\section{Populasi}

Menurut Ferdinand, 2006:223 (dalam jurnal Prajawantoro, 2016:109) Populasi, ialah gabungan seluruh elemen yang berbentuk peristiwa, hal, atau orang yang memiliki karakteristik yang serupa yang menjadi pusat semesta penelitian. Populasi dalam penelitian ini adalah konsumen FIFGROUP Cabang Yosowilangun Kabupaten Lumajang yang pernah atupun baru. Data sekarang yang terdapat di sistem berjumlah 457 konsumen.

\section{Sampel}

Menurut Sugiono, 2006:91 (dalam jurnal Prajawantoro, 2016:109)Sampel, adalah bagian dari jumlah dan karakteristik yang dimiliki olehpopulasi tersebut. Teknik pengambilan 
sampel dalam penelitian ini yaitu purposive sampling. Purposive sampling menurut Arikunto (2006) adalah teknik mengambil sampel dengan tidak berdasarkan random, daerah atau strata, melainkan berdasarkan atas adanya pertimbangan yang berfokus pada tujuan tertentu. Adapun pertimbangannya adalah sebagai berikut :

1. Konsumen pernah membeli jasa di FIFGROUP Yosowilangun memilih jaminan BPKB sepeda motor.

2. Pembiayaan kredit sepeda motor baru.

Dalam Sugiono (2012:91) menyarankan tentang ukuraan sampel bila dalam penelitian akan melakukan analisis dengan multivariate (kolerasi atau regresi ganda misalnya), maka jumlah anggota sampel minimal 10 kali dari jumlah variabel yang diteliti. Dengan variabel penelitian ada 5 , jadi jumlah anggota sampel $=12 \times 5=60$. Maka jumlah sampel dalam penelitian ini adalah 60 orang.

\section{Metode Pengumpulan Data}

a. Wawancara adalah teknik pengumpulan data untuk menggali informasi dari responden yang dibutuhkan untuk penelitian dengan cara tanya jawab secara langsung mengenai pengaruh kualitas pelayanan terhadap kepuasan konsumen pada FIFGROUP cabang Yosowilangun Kabupaten Lumajang.

b. Kuesioner, adalah teknik pengumpulan data dengan cara memberikan beberapa pertanyaan-pertanyaan secara tertulis kepada konsumen.

c. Studi pustaka, yang berhubungan dengan kajian teoritis dan referensi lain yang berkaitan dengan dalam penelitian.

\section{ANALISIS HASIL PENELITIAN}

\section{Uji Validitas}

Uji validitas digunakan untuk mengukur sah atau valid tidaknya sesuatu kuesioner. Uji signifikan dilakukan dengan membandingkan nilai $r$ hitung dengan nilai $r$ tabel. Jika $r$ hitung > dari r tabel, maka dapat dikatakan data penelitian tersebut valid dan sebaliknya. Pengujian validitas dilakukan dengan menggunakan uji satu sisi, taraf signifikan 5\% dengan $\mathrm{df}=\mathrm{n}-2$ (Arikunto, 2006

;168). Df $=60-2=58$, maka $\mathrm{r}$ tabelnya $=0,254$. 
Tabel Uji Validitas Bukti Fisik

\begin{tabular}{|l|l|l|l|}
\hline Variabel & R Hitung & $\begin{array}{l}\text { R Tabel } \\
(5 \%)\end{array}$ & Keterangan \\
\hline Bukti Fisik_1 & 0,764 & 0,254 & Valid \\
\hline Bukti Fisik_2 & 0,570 & 0,254 & Valid \\
\hline Bukti Fisik_3 & 0,765 & 0,254 & Valid \\
\hline
\end{tabular}

Berdasarkan tabel diatas menunjukkan bahwa nilai dari $r$ hitung $>r$ tabel pada taraf signifikansi 5\% diketahui $r$ tabel sebesar 0.254 dan $\mathrm{r}$ hitung dari ketiga indikator lebih besar dari angka tersebut sehingga dapat disimpulkan bahwa butir pernyataan pada instrument bukti fisik dinyatakan valid.

\section{Keandalan}

Tabel Uji Validitas Keandalan

\begin{tabular}{|l|l|l|l|}
\hline Variabel & R Hitung & $\begin{array}{l}\text { R Tabel } \\
(5 \%)\end{array}$ & Keterangan \\
\hline Keandalan_1 & 0,737 & 0,254 & Valid \\
\hline Keandalan_2 & 0,726 & 0,254 & Valid \\
\hline Keandalan_3 & 0,601 & 0,254 & Valid \\
\hline
\end{tabular}

Berdasarkan tabel diatas menunjukkan bahwa nilai dari $r$ hitung $>r$ tabel pada taraf signifikansi 5\% diketahui $r$ tabel sebesar 0.254 dan $r$ hitung dari ketiga indikator lebih besar dari angka tersebut sehingga dapat disimpulkan bahwa butir pernyataan pada instrument keandalan dinyatakan valid.

\section{Daya Tanggap}

Tabel Uji Validitas Daya Tanggap

\begin{tabular}{|l|l|l|l|}
\hline Variabel & R Hitung & $\begin{array}{l}\text { R Tabel } \\
(5 \%)\end{array}$ & Keterangan \\
\hline Daya Tanggap_1 & 0,839 & 0,254 & Valid \\
\hline Daya Tanggap_2 & 0,859 & 0,254 & Valid \\
\hline
\end{tabular}

Berdasarkan tabel diatas menunjukkan bahwa nilai dari $r$ hitung $>r$ tabel pada taraf signifikansi 5\% diketahui $r$ tabel sebesar 0.254 dan $r$ hitung dari kedua indikator lebih besar dari angka tersebut sehingga dapat disimpulkan bahwa butir pernyataan pada instrument daya tanggap dinyatakan valid. 


\section{Jaminan}

Tabel Uji Validitas Jaminan

\begin{tabular}{|l|l|l|l|}
\hline Variabel & R Hitung & $\begin{array}{l}\text { R Tabel } \\
(5 \%)\end{array}$ & Keterangan \\
\hline Jaminan_1 & 0,692 & 0,254 & Valid \\
\hline Jaminan_2 & 0,566 & 0,254 & Valid \\
\hline Jaminan_3 & 0,677 & 0,254 & Valid \\
\hline
\end{tabular}

Berdasarkan tabel diatas menunjukkan bahwa nilai dari $r$ hitung $>r$ tabel pada taraf signifikansi 5\% diketahui $r$ tabel sebesar 0.254 dan $r$ hitung dari ketiga indikator lebih besar dari angka tersebut sehingga dapat disimpulkan bahwa butir pernyataan pada instrument jaminan dinyatakan valid.

\section{Empati}

Tabel Uji Validitas Empati

\begin{tabular}{|l|l|l|l|}
\hline Variabel & R Hitung & $\begin{array}{l}\text { R Tabel } \\
(5 \%)\end{array}$ & Keterangan \\
\hline Empati_1 & 0,728 & 0,254 & Valid \\
\hline Empati_2 & 0,678 & 0,254 & Valid \\
\hline Empati_3 & 0,608 & 0,254 & Valid \\
\hline
\end{tabular}

Berdasarkan tabel diatas menunjukkan bahwa nilai dari $r$ hitung $>r$ tabel pada taraf signifikansi 5\% diketahui $r$ tabel sebesar 0.254 dan $r$ hitung dari ketiga indikator lebih besar dari angka tersebut sehingga dapat disimpulkan bahwa butir pernyataan pada instrument empati dinyatakan valid.

\section{Kepuasan Konsumen}

Tabel Uji Validitas Kepuasan Konsumen

\begin{tabular}{|l|l|l|l|}
\hline Variabel & R Hitung & $\begin{array}{l}\text { R Tabel } \\
(5 \%)\end{array}$ & Keterangan \\
\hline Kepuasan Konsumen_3 & 0,616 & 0,254 & Valid \\
\hline Kepuasan Konsumen_3 & 0,767 & 0,254 & Valid \\
\hline Kepuasan Konsumen_3 & 0,853 & 0,254 & Valid \\
\hline
\end{tabular}

Berdasarkan tabel diatas menunjukkan bahwa nilai dari $r$ hitung $>r$ tabel pada taraf signifikansi 5\% diketahui $r$ tabel sebesar 0.254 dan $r$ hitung dari ketiga indikator lebih besar dari angka tersebut sehingga dapat disimpulkan bahwa butir pernyataan pada instrument kepuasan konsumen dinyatakan valid. 


\section{Uji Reliabilitas}

Tabel Uji Realiabilitas

\begin{tabular}{|l|l|l|l|}
\hline Variabel & Cronbach's Alpha & $\begin{array}{l}\text { R Tabel (5\%) } \\
(\mathbf{5 8})\end{array}$ & Keterangan \\
\hline X1 & 0,487 & 0,254 & Reliabel \\
\hline X2 & 0,441 & 0,254 & Reliabel \\
\hline X3 & 0,612 & 0,254 & Reliabel \\
\hline X4 & 0,303 & 0,254 & Reliabel \\
\hline X5 & 0,393 & 0,254 & Reliabel \\
\hline Y & 0,609 & 0,254 & Reliabel \\
\hline
\end{tabular}

Dari tabel diatas dengan melihat Cronbach Alpha dimana suatu variable dapat bernilai reliable apabila memberikan nilai Cronbach Alpha > 0,05. Dapat diketahui bahwa hasil uji instrument dan setiap variable bernilai > 0,05, maka dapat disimpulkan dari seluruh instrumen yang telah dibuat adalah valid dan reliabel dan juga dapat digunakan untuk mengetahui Pengaruh variabel independen terhadap variabel dependennya.

\section{Uji Asumsi Klasik}

\section{Uji Normalitas}

Penelitian ini menggunakan uji kolmogorov-smirnov. Hasil uji sebagai berikut :

\section{Tabel Uji Normalitas}

One-Sample Kolmogorov-Smirnov Test

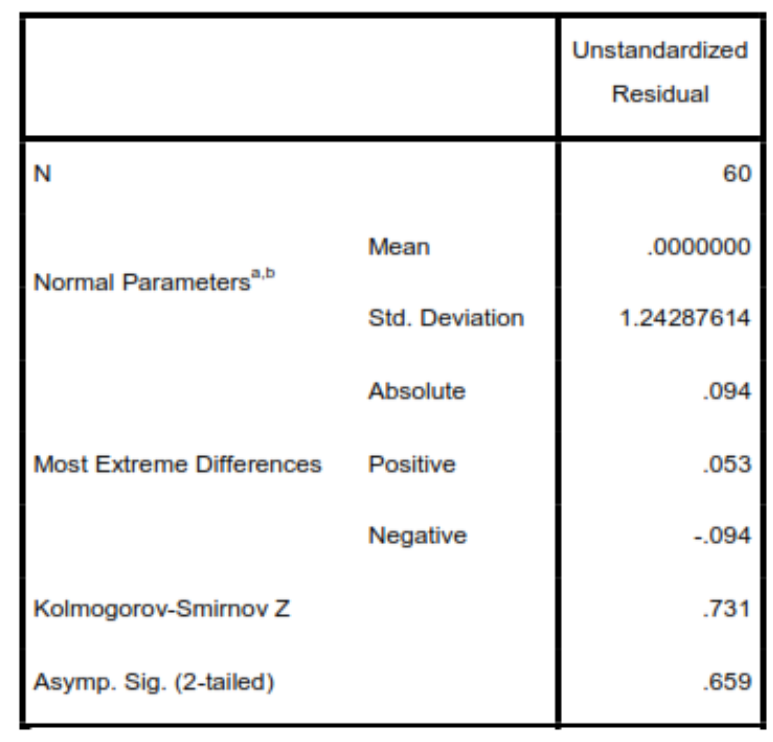

a. Test distribution is Normal.

b. Calculated from data.

Sumber : Data diolah, 2021 
Dari hasil uji yang telah dilakukan dengan menggunakan aplikasi SPSS 17, diperoleh nilai signifikansi data sebesar 0,659 yang artinya > 0,05 sehingga dapat disimpulkan bahwa data berdistribusi normal dan dapat digunakan dalam penelitian.

\section{Uji Multikolonieritas}

Dalam penelitian ini untuk mendeteksi adanya multikolinearitas dapat dilakukan dengan mencari besarnya Variance Infaction Factor (VIF) dan nilai Tolerance. Jika nilai VIF kurang dari 10 dan nilai Tolerance lebih dari 0.10 maka regresi bebas dari multikolinearitas. Hasil dari uji multikolinieritas dengan menggunakan program SPSS release 17.0 adalah nilai Tolerance menunjukkan tidak ada variabel independen yang memiliki nilai Tolerance kurang dari 0.10 yang berarti tidak ada korelasi antar variabel independen.

\section{Tabel Uji Multikolinieritas}

\begin{tabular}{|c|c|c|c|c|c|c|c|}
\hline \multicolumn{8}{|c|}{ Coefficients ${ }^{a}$} \\
\hline \multirow[t]{2}{*}{ Model } & \multicolumn{2}{|c|}{$\begin{array}{l}\text { Unstandardized } \\
\text { Coefficients }\end{array}$} & \multirow{2}{*}{$\begin{array}{l}\text { Standardized } \\
\text { Coefficients } \\
\text { Beta }\end{array}$} & \multirow[t]{2}{*}{$\mathbf{T}$} & \multirow[t]{2}{*}{ Sig. } & \multicolumn{2}{|c|}{$\begin{array}{l}\text { Collinearity } \\
\text { Statistics }\end{array}$} \\
\hline & $\mathrm{B}$ & Std. Error & & & & Tolerance & VIF \\
\hline (Constant) & -1.623 & 1.763 & & -.920 & .362 & & \\
\hline Bukti Fisik & .056 & .146 & .044 & .384 & .703 & .580 & 1.724 \\
\hline Keandalan & .147 & .177 & .129 & .828 & .411 & .321 & 3.113 \\
\hline Daya Tanggap & .021 & .163 & .015 & .127 & .899 & .537 & 1.862 \\
\hline Jaminan & .730 & .160 & .558 & 4.560 & .000 & .517 & 1.933 \\
\hline Empati & .156 & .194 & .116 & .805 & .424 & .371 & 2.697 \\
\hline
\end{tabular}

a. Dependent Variable: Kepuasan Konsumen

Dari hasil data diatas yang telah diolah menggunakan SPSS 17 maka dapat diketahui bahwa model regresi yang diajukan untuk variabel bukti fisik, keandalan, daya tanggap, jaminan dan empati tidak terjadi gejala multikolonieritas karena nilai VIF masih diantara 110 dan tolerance lebih dari

0.10 .

\section{Uji Heterokedastisitas}

Untuk menguji apakah dalam model regresi terjadi ketidaksamaan variance dari residual satu pengamatan ke pengamatan lain, maka dalam penelitian ini menggunakan uji glejser untuk merespon variabel $\mathrm{x}$ sebagai variabel independen dengan nilai 
absolute unstandardized residual sebagai variabel dependen. Apabila hasil uji diatas level segnifikan >0,05 berarti tidak terjadi heteroskedastisitas dan sebaliknya apabila level dibawah segnifikan $<0,05$ berarti terjadi heteroskedastisitas (Ghozali, 2006).

Tabel Uji Heterokedastisitas

\begin{tabular}{|c|c|c|c|c|c|}
\hline \multicolumn{6}{|c|}{ Coefficients $^{\mathrm{a}}$} \\
\hline \multirow[t]{2}{*}{ Model } & \multicolumn{2}{|c|}{ Unstandardized Coefficients } & \multirow{2}{*}{$\begin{array}{c}\text { Standardized } \\
\text { Coefficients } \\
\text { Beta }\end{array}$} & \multirow[t]{2}{*}{$\mathrm{T}$} & \multirow[t]{2}{*}{ Sig. } \\
\hline & B & Std. Error & & & \\
\hline (Constant) & 3.021 & .982 & & 3.076 & .003 \\
\hline Bukti Fisik & -.087 & .081 & -.177 & -1.072 & .288 \\
\hline Keandalan & -.118 & .099 & -.265 & -1.197 & .237 \\
\hline Daya Tanggap & .084 & .091 & .158 & .921 & .361 \\
\hline Jaminan & .050 & .089 & .097 & .559 & .579 \\
\hline Empati & -.067 & .108 & -.127 & -.618 & .539 \\
\hline
\end{tabular}

a. Dependent Variable: Abs_Res

Berdasarkan hasil pehitungan data diatas dengan menggunakan SPSS 17 dapat diketahui bahwa tidak ada gangguan hesteroskedastisitas yang terjadi, artinya nilai sig. $>0$, 05. Maka dapat disimpulkan tidak ada masalah hesteoskedastisitas pada variabel independennya.

\section{Analisis Regresi Linear Berganda}

Uji regresi linier berganda bertujuan untuk melihat pengaruh tangible, reliability, responsiveness, assurance, dan empathy terhadap kepuasan konsumen dengan menggunakan persamaan linier. Adapun rumus yang digunakan sebagai berikut :

$$
\mathrm{Y}=\mathrm{a}+\mathrm{b}_{1} \mathrm{X}_{1}+\mathrm{b}_{2} \mathrm{X}_{2}+\mathrm{b}_{3} \mathrm{X}_{3}+\mathrm{b}_{4} \mathrm{X}_{4}+\mathrm{b}_{5} \mathrm{X}_{5}+\mathrm{e}
$$


Tabel Analisis Regresi Linear Berganda

\begin{tabular}{|c|c|c|c|c|c|c|c|}
\hline \multicolumn{8}{|c|}{ Coefficients ${ }^{a}$} \\
\hline \multirow[t]{2}{*}{ Model } & \multicolumn{2}{|c|}{$\begin{array}{l}\text { Unstandardized } \\
\text { Coefficients }\end{array}$} & \multirow{2}{*}{$\begin{array}{c}\text { Standardized } \\
\text { Coefficients }\end{array}$} & \multirow[t]{2}{*}{$T$} & \multirow[t]{2}{*}{ Sig. } & \multicolumn{2}{|c|}{$\begin{array}{l}\text { Collinearity } \\
\text { Statistics }\end{array}$} \\
\hline & B & Std. Error & & & & Tolerance & VIF \\
\hline (Constant) & -1.623 & 1.763 & & -.920 & .362 & & \\
\hline Bukti Fisik & .056 & .146 & .044 & .384 & .703 & .580 & 1.724 \\
\hline Keandalan & .147 & .177 & .129 & .828 & .411 & .321 & 3.113 \\
\hline Daya Tanggap & .021 & .163 & .015 & .127 & .899 & .537 & 1.862 \\
\hline Jaminan & .730 & .160 & .558 & 4.560 & .000 & .517 & 1.933 \\
\hline Empati & .156 & .194 & .116 & .805 & .424 & .371 & 2.697 \\
\hline
\end{tabular}

a. Dependent Variable: Kepuasan Konsumen

$Y=-1,623+0,056 \mathrm{X} 1+0,147 \mathrm{X} 2+0,021 \mathrm{X} 3+0,730 \mathrm{X} 4+0,156 \mathrm{X} 5$

Persamaan regresi linier diatas menunjukkan hubungan antara variabel independen dengan variabel dependen secara parsial, dari persamaan tersebut maka dapat di ambil kesimpulan sebagai berikut :

1. Konstanta adalah $-1,623$, artinya jika variabel bukti fisik, keandalan, daya tanggap, jaminan dan empati diasumsikan atau dianggap nol maka variabel kepuasan konsumen nilainya negatif 1,623 .

2. Nilai koefisien regresi bukti fisik adalah positif 0,056 artinya jika variabel bukti fisik meningkat maka kepuasan konsumen akan meningkat sebesar 0,056 dan kenaikan ini searah, dengan asumsi keandalan, daya tanggap, jaminan dan empati adalah nol.

3. Nilai koefisien regresi $\mathrm{X} 2$ adalah positif 0,147 artinya jika variabel keandalan meningkat maka kepuasan konsumen akan meningkat sebesar 0,147 dan kenaikan ini searah, dengan asumsi bukti fisik, daya tanggap, jaminan dan empati adalah nol.

4. Nilai koefisien regresi $X 3$ adalah positif 0,021 artinya jika variabel $X 3$ meningkat maka kepuasan konsumen akan meningkat sebesar 0,021 dan kenaikan ini 
searah, dengan asumsi bukti fisik, keandalan, jaminan dan empati adalah nol.

5. Nilai koefisien regresi $\mathrm{X} 4$ adalah positif 0,730 artinya jika variabel $\mathrm{X} 4$ meningkat maka kepuasan konsumen akan meningkat sebesar 0,730 dan kenaikan ini searah, dengan asumsi bukti fisik, keandalan, daya tanggap dan empati adalah nol.

6. Nilai koefisien regresi X5 adalah positif 0,156 artinya jika variabel X5 meningkat maka kepuasan konsumen akan meningkat sebesar 0,056 dan kenaikan ini searah, dengan asumsi bukti fisik, keandalan, daya tanggap dan jaminan adalah nol.

\section{Koefisien Determinasi (R2)}

Koefiesien determinasi (R2) pada intinya mengukur seberapa jauh kemampuan model dalam menerangkan variasi variabel dependen. Nilai koefisien determinasi adalah nol dan satu. untuk mengukur seberapa jauh kemampuan model dalam menerangkan variasi variabel independen. Nilai koefisien determinasi adalah antara nol dan satu. Nilai $\mathrm{R}^{2}$ yang kecil berarti kemampuan variabel- variabel independen dalam menjelaskan variasi variabel dependen sangat terbatas.

\section{Tabel Koefisien Determinasi}

Model Summary

\begin{tabular}{|l|r|r|r|r|}
\hline Model & $\mathrm{R}$ & $\mathrm{R}$ Square & $\begin{array}{c}\text { Adjusted R } \\
\text { Square }\end{array}$ & $\begin{array}{c}\text { Std. Error of the } \\
\text { Estimate }\end{array}$ \\
\hline 1 & $.763^{\mathrm{a}}$ & .581 & .543 & 1.299 \\
\hline
\end{tabular}

a. Predictors: (Constant), Empati, Bukti Fisik, Daya Tanggap, Jaminan,

Keandalan

Berdasarkan tabel diatas dapat di ketahui bahwa koefisiensi terdapat pada nilai Adjusted R square sebesar 0, 543 . Hal ini berarti kemampuan variabel bukti fisik, keandalan, daya tanggap, jaminan dan empati dalam menjelaskan variabel kepuasan konsumen adalah sebesar 54,3\% sisanya yaitu 45,7 \% dijelaskan oleh varibel lain yang tidak di bahas dalam penelitian ini.

\section{Uji Hipotesis}

\section{Uji t}

Menunjukkan seberapa jauh pengaruh satu variabel independen secara individual dalam menerangkan variasi variabel dependen menurut Ghozali, 2007 (dalam jurnal Prajawantoro 2016:111). Hipotesis setatistiknya yaitu: H0 : b = 0 (tidak ada pengaruh antara variabel independen secara individu terhadap variabel dependen). H1 : b > 0 (ada pengaruh positif antara variabel independen secara individu terhadap variabel dependen). Adapun hasil 
ujinya adalah sebagai berikut :

$$
\text { t tabel }=(\alpha / 2 ; n-k-1)
$$

Keterangan :

$$
\begin{aligned}
& \alpha=0,05 \\
& \mathrm{n}: \text { Jumlah Sampel }=60 \\
& \mathrm{k}: \text { Jumlah Variabel Bebas }=5 \\
& \text { maka nilai t tabel dalam penelitian ini adalah : } \\
& \mathrm{t} \text { tabel }=(0,05 / 2 ; 60-5-1) \\
& \quad=(0,025 ; 54) \text { maka nilai } \mathrm{t} \text { tabel }=2,004 \text { (dapat dilihat pada kolom distribusi nilai } \mathrm{t} \\
& \quad \text { tabel })
\end{aligned}
$$

\begin{tabular}{|c|c|c|c|c|c|c|c|}
\hline \multirow[t]{2}{*}{ Model } & \multicolumn{2}{|c|}{$\begin{array}{l}\text { Unstandardized } \\
\text { Coefficients }\end{array}$} & \multirow{2}{*}{$\begin{array}{c}\text { Standardized } \\
\text { Coefficients } \\
\text { Beta }\end{array}$} & \multirow[t]{2}{*}{$\mathrm{T}$} & \multirow[t]{2}{*}{ Sig. } & \multicolumn{2}{|c|}{$\begin{array}{l}\text { Collinearity } \\
\text { Statistics }\end{array}$} \\
\hline & B & Std. Error & & & & Tolerance & VIF \\
\hline (Constant) & -1.623 & 1.763 & & -.920 & .362 & & \\
\hline Bukti Fisik & .056 & .146 & .044 & .384 & .703 & .580 & 1.724 \\
\hline Keandalan & .147 & .177 & .129 & .828 & .411 & .321 & 3.113 \\
\hline Daya Tanggap & .021 & .163 & .015 & .127 & .899 & .537 & 1.862 \\
\hline Jaminan & .730 & .160 & .558 & 4.560 & .000 & .517 & 1.933 \\
\hline Empati & .156 & .194 & .116 & .805 & .424 & .371 & 2.697 \\
\hline
\end{tabular}

Tabel Uji t

Coefficients"

a. Dependent Variable: Kepuasan Konsumen

Dari hasil uji t diatas dapat di ambil kesimpulan bahwa :

a. Dari hasil analisis data dan pengujian yang telah dilakukan menunjukkan nilai $t$ hitung sebesar $0,384<\mathrm{t}$ tabel 2,004 artinya nilai tersebut tidak signifikan dan menunjukkan bahwa tidak terdapat pengaruh Bukti Fisik terhadap kepuasan konsumen pada FIFGROUP Cabang Yosowilangun Kabupaten Lumajang.

b. Dari hasil analisis data dan pengujian yang telah dilakukan menunjukkan nilai $\mathrm{t}$ hitung sebesar $0,828<\mathrm{t}$ tabel 2,004 artinya nilai tersebut tidak signifikan dan menunjukkan bahwa tidak terdapat pengaruh Keandalan terhadap kepuasan konsumen pada FIFGROUP Cabang Yosowilangun Kabupaten Lumajang.

c. Dari hasil analisis data dan pengujian yang telah dilakukan menunjukkan nilai $t$ hitung sebesar $0,127<\mathrm{t}$ tabel 2,004 artinya nilai tersebut tidak signifikan dan 
menunjukkan bahwa tidak terdapat pengaruh Daya Tanggap terhadap kepuasan konsumen pada FIFGROUP Cabang Yosowilangun Kabupaten Lumajang.

d. Dari hasil analisis data dan pengujian yang telah dilakukan menunjukkan nilai $\mathrm{t}$ hitung sebesar 4,560 > t tabel 2,004 artinya nilai tersebut signifikan dan menunjukkan bahwa terdapat pengaruh Jaminan terhadap kepuasan konsumen pada FIFGROUP Cabang Yosowilangun Kabupaten Lumajang.

e. Dari hasil analisis data dan pengujian yang telah dilakukan menunjukkan nilai $\mathrm{t}$ hitung sebesar $0,805<\mathrm{t}$ tabel 2,004 artinya nilai tersebut tidak signifikan dan menunjukkan bahwa tidak terdapat pengaruh Empati terhadap kepuasan konsumen pada FIFGROUP Cabang Yosowilangun Kabupaten Lumajang.

\section{Uji F}

Digunakan untuk menguji pengaruh variabel independen secara bersama terhadap variabel dependen. Kriteria untuk menguji hipotesis adalah menurut Ghozali, 2007 (dalam jurnal Prajawantoro 2016:110-111). Perumusan hipotesisnya yaitu: Ho : b $=0$ : tidak ada pengaruh antara variabel independen secara bersama terhadap variabel dependen. $\mathrm{H} 1: \mathrm{b}$ $>0$ : ada pengaruh positif antara variabel independen secara bersama terhadap variabel dependen. Dan inilah hasil ujinya :

$\mathrm{F}$ tabel $=(\mathrm{k} ; \mathrm{n}-\mathrm{k})$ Keterangan :

$\mathrm{k}=$ Jumlah variabel bebas $\mathrm{n}=$ jumlah sampel

$\mathrm{F}$ tabel $=(5 ; 60-5)=(5 ; 55)$ maka nilai $\mathrm{F}$ tabel $=2,380$ (dapat dilihat pada kolom distribusi nilai $f$ tabel)

\section{Tabel Uji F}

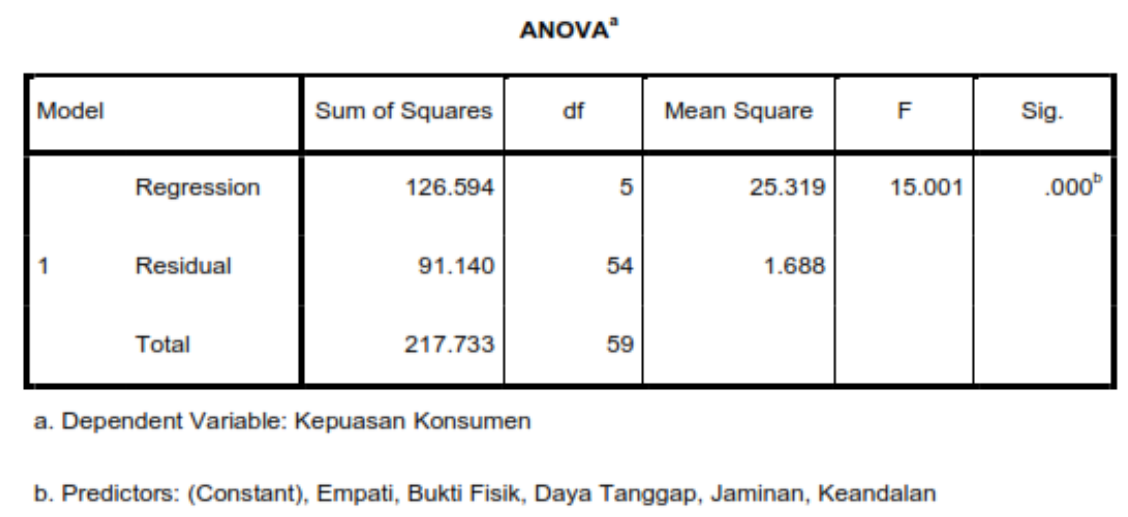

Dari hasil pengujian pada tabel diatas dapat di lihat pada nilai $\mathrm{f}$ hitung sebesar 15,001 dengan nilai $F$ tabel adalah 2,380 sehingga nilai $\mathrm{f}$ hitung > $\mathrm{f}$ tabel atau 15,001 > 2,380 dan tingkat signifikansi $0,000<0,05$ maka Ho di tolak dan Ha diterima, sehingga dapat disimpulkan bahwa variabel X1-X5 secara bersama-sama berpengaruh signifikan 
terhadap variabel Y Kepuasan Konsumen FIFGroup Cabang Yosowilangun Kabupaten Lumajang.

\section{SIMPULAN}

Dari hasil pembahasan dan analisis data yang telah dilakukan, maka dapat ditarik kesimpulan sebagai berikut :

a. Secara parsial variabel kualitas pelayanan yaitu Jaminan berpengaruh secara signifikan terhadap Kepuasan Konsumen pada FIFGroup Yosowilangun Kabupaten cabang Lumajang. Namun untuk variabel kualitas pelayanan lainnya yang meliputi Bukti Fisik, Keandalan, Daya Tanggap dan Empati Secara parsial tidak berpengaruh terhadap Kepuasan Konsumen FIFGroup cabang Yosowilangun Kabupaten Lumajang.

b. Secara simultan variabel kualitas layanan yang meliputi Bukti Fisik, Keandalan, Daya Tanggap, Jaminan, dan Empati berpengaruh terhadap Kepuasan Konsumen FIFGroup Cabang Yosowilangun Kabupaten Lumajang.

\section{DAFTAR PUSTAKA}

Apriyani, Dwi Aliyyah dan Sunarti, 2017, Pengaruh Kualitas Pelayanan Terhadap Kepuasan Konsumen (Survei Pada Konsumen The Little A Coffee Shop Sidoarjo).

Atmawati, Rustika dan wahyudi, M., 2004, Analisis Pengaruh Kualitas Pelayanan Terhadap Kepuasan Konsumen Pada Matahari Departement Store Di Solo Grand Mall.

Darmawan, Kusnanto, 2018, Dampak Kualitas Pelayanan Terhadap Kepuasan Dan Loyalitas Pelanggan.

Ghozali, Imam. 2006. Ekonometrika. Semarang. Undip

Ghozali, Imam. 2013. Aplikasi Analisis Multivariate Dengan Program IBM SPSS 21. Edisi 7. Semarang. Undip.

Mustaqim, Fata Mufti, 2017, Pengaruh Kualitas Pelayanan Terhadap Kepuasan Konsumen $P T$.

FIFGROUP Cabang Samarinda.

Normasari, Selvi dkk, 2013, Pengaruh Kuaitas Pelayanan Terhadap Kepuasan Pelanggan,

Citra Perusahaan Dan Loyalitas Pelanggan (Survei Pada Tamu Pelanggan Yang Menginap Di Hotel Pelangi Malang).

Panjaitan, Januar Efendi dan Yuliati, Ai Lili, 2016, Pengaruh Kualitas Pelayanan Terhadap Kepuasan Pelanggan Pada JNE Cabang Bandung.

Prajawantoro, 2016, Pengaruh Kualitas Pelayanan Terhadap Kepuasan Konsumen Pada PT. 
Adira

Dinamika Multi Finace Cabang Lampung Mobil. Vol. 7 No. 1 :ISSN 2087-0701.

Prasetio, Ari, 2012, Pengaruh Kualitas Pelayanan Dan Harga Terhadap Kepuasan Pelanggan.

Runtunuwu, Johanes Gerardo, 2014, Pengaruh Kualitas Produk, Harga dan Kualitas Pelayanan

Terhadap Kepuasan Pengguna Cafe Dan Resto Cabana Manado.

Sembiring, Inka Jenita dkk, 2014, Pengaruh Kualitas Produk Dan Kualitas Pelayanan Terhadap Kepuasan Pelanggan Dalam Membentuk Loyalitas Pelanggan (Studi Pada Pelanggan McDonald's MT.Haryono Malang).

Sugiyono. 2010. Metode Penelitian Kuantitatif Kualitatif dan R\&D. CV Alfabeta.

Bandung. Suparyanto \& Rosad. 2015. Manajemen Pemasaran. IN MEDIA. Bogor.

Sweeney, J.C and Soutar. 2001. Customer Perceived Value The Development of A Multiple Item

Scale. Jurnal of Retailing, Vol. 77, pp. 203-220.

Suprayogi, Hari dkk, 2019, Pengaruh Dimensi Kualitas Pelayanan Terhadap Kepuasan Pelanggan Pada PT. PLN (Persero) ULP Lumajang (Studi Kasus Pada Pelanggan Pasang Baru Rumah Tangga Daya 900 Va).

Tjiptono, Fandy. 2014. Pemasaran Jasa. Yogyakarta :Andi Offset

Wijayanto, Kusuma, 2015, Pengaruh Kualitas Pelayanan Terhadap Kepuasan Dan Loyalitas Nasabah Bank. 